\title{
The Effect of Forest Healing Program on Job Search Stress, Career Decision-making Self-efficacy, and Career Resilience among Nursing College Students
}

\author{
In-kyung Kim1), Mi-ja Lee2)
}

\begin{abstract}
This study was conducted to analyze the effect of forest healing program on job search stress, career decision-making self-efficacy, and career resilience of nursing college students. The student participants included 33 fourth-grade students at the Department of Nursing of S University in Gangwon-do. The forest healing program was conducted in 6 sessions once a week from October 17th to November 19th, of 2019. The contents of the forest healing program included of climate, spirit, exercise, diet, and plant elements. As a result, the career decision-making self-efficacy increased from 3.31 in pre-test to 3.49 in post-test analysis. The difference was statistically significant $(\mathrm{P}=.018)$. However, there was no significant difference in job search stress, career resilience, and serum cortisol $(\mathrm{P}=.105 . \mathrm{P}=.292, \mathrm{P}=.217)$. The findings suggest that the forest healing program had a positive effect on reducing negative emotions such as employment stress among the research participants and increased positive emotions such as career decision-making self-efficacy and career elasticity.
\end{abstract}

Keywords: Forest, Program, Stress, Self-efficacy, Resilience, Nursing Student

\section{Introduction}

Youth unemployment, a serious social problem in Korea, puts career stress on college students. The number of youth unemployed in Korea increased by 28.3\% (9.0 million) over 10 years from 318,000 in 2008 to 408,000 in 2018[1]. According to Shin Hyun-gyun and Jang Jae-yun[2], $79 \%$ of the 2,530 fourth-year college students who are preparing for employment experiencing significant levels of job stress, and college students are most unhappy about finding employment[3][4]. Nursing students are no exception. Particularly, even if they are employed in a hospital the stress increases gradually. Because the employment complete after passing the

Received(November 19, 2019), Review Result(1st: December 24, 2019, 2nd: February 04, 2020), Accepted(April 25, 2020)

1) (Professor) 24465 Dept. Nurising, Songgok Univ., Songgokdaehakkil 34, Namsan-myun, Chuncheon-city, Kangwon-do, Korea email: kink@songgok.ac.kr

2) (Professor, Corresponding Author) 24465 Dept. Nurising, Songgok Univ., Songgokdaehakkil 34, Namsan-myun, Chuncheon-city, Kangwon-do, Korea

email: mjlee@songgok.ac.kr 
The Effect of Forest Healing Program on Job Search Stress, Career Decision-making Self-efficacy, and Career Resilience among Nursing College Students

national examination. In addition, career decision-making self-efficacy, which is defined as the self-confidence to implement career-related tasks[5], is the most important factor that college students need to improve while the majority of nursing college students decide on careers at clinical sites. However, in the rapidly changing work environment, the career growth and development of college students depend on positive intervention and utilization of individual strengths and resources and a flexible attitude or ability to manage their career by overcoming career obstacles is required[6]. Also adaptability and resilience in the profession are needed[7]. Therefore the importance of career resilience is highlighted by the ability of individuals to cope with uncertain future and unforeseen career crises in the rapidly changing world of work. It is a key factor in overcoming barriers[8]. Previous studies related to job stress of college students found that job stress reduced concentration, positive self-esteem and self-elasticity[9], and also reduced the happiness perceived by college students[10]. Career-determining self-efficacy had a mediating effect on the relationship with job stress[11]. Several proven studies have been conducted[12]. Career resilience is an important characteristic to cope with job stress flexibly and is a key element in overcoming career stress and career barriers[8].

Interest in forest healing is gradually increasing as research shows that various forest healing programs contribute to restoration and improvement of physical and mental health in response to activities of autonomic nervous, endocrine, and immune systems. Forest healing activity enhances emotional stability via autonomic nerve balance and parasympathetic nerve activation[13]. It can alleviate stress[14]. In addition, the positive effect of forest healing activity on physical and mental health have been demonstrated[15]. Previous studies explored the effects of forest healing programs, especially weekend programs at urban forests on workers' resilience and happiness[5], depression and self-esteem of single mothers[16]. Studies focused on social improvement, depression and anxiety reduction, including the impact on family cohesion and family relations improvement, parental satisfaction[17], development of effectiveness measurement tools in forest experience[18], and qualitative studies analyzing forest healing experiences[19]. However, few studies related to the careers of college students. Therefore, the purpose of this study is to examine the effects of forest healing program on job search stress, efficiency of career decision-making self-efficacy and career resilience.

\section{Research Method}

\subsection{Articipants and Place}


This study was conducted with 4th grade nursing students from S University in Chuncheon-si, Gangwon-do. The study participants included the entire class of 4 th graders. The researchers received a consent form fully explaining that the study purpose and contents, and that there were no disadvantages due to withdrawal from the study. The participants were 3 male and 30 female students who voluntarily agreed to participate in the study. The study was a single group pre-test post-test design. The location of this study was a low slope forest path mixed with deciduous and coniferous trees and a flat space surrounded by forests to run the program. The representative vegetation was mainly composed of 50-year-old pine trees among a mix of pine, oak, and cassia vegetations. The study conducted in a place surrounded by various herbs and trees, and includes elements of forest healing. It was located in the school and was easily accessible to students and was appropriate to implement the program.

\subsection{Research Procedure}

This study was conducted over a total of six sessions of forest healing program for 60 minutes once a week starting from October 17th to November 19th, 2019. The program included climate, spirit, exercise, diet, and plant elements. The location of the program was the S University Forest. The study used the self-written questionnaire method, in which participants completed the questionnaire directly before and after the program commenced. The researchers composed a forest healing program based on previous studies[20][21] with five forest healing experts. The details of the activity are shown in [Table 1]. Each session of the procedure consisted of introduction, activity, and finishing stage. In the introduction stage, students introduced the activities with their students and motivated the program. The activities last approximately 40 minutes and were assigned subjects for each session. It was designed to enable work in a free atmosphere. In the final stage, the introduction and activity stages were used to express feelings and thoughts and provide feedback.

[Table 1] Forest Healing Program

\begin{tabular}{|c|c|c|c|}
\hline Session & Topic & Program goal & Contents \\
\hline 1st & $\begin{array}{c}\text { Getting to meet the } \\
\text { forest }\end{array}$ & $\begin{array}{c}\text { Understanding the forest where activities } \\
\text { are held and valued }\end{array}$ & $\begin{array}{c}\text { Getting consent from } \\
\text { the forest }\end{array}$ \\
\hline 2nd & $\begin{array}{c}\text { Developing } \\
\text { self-identity }\end{array}$ & $\begin{array}{c}\text { Understanding forest ecology and survival } \\
\text { strategy }\end{array}$ & $\begin{array}{c}\text { Expressing thoughts } \\
\text { with ropes } \\
\text { Expression of one's own body, thought and } \\
\text { mind through the forest }\end{array}$ \\
\hline 3rd & Awakening 5 & $\begin{array}{c}\text { Meditation by breathing } \\
\text { in forest }\end{array}$ \\
\hline
\end{tabular}


The Effect of Forest Healing Program on Job Search Stress, Career Decision-making Self-efficacy, and Career Resilience among Nursing College Students

\begin{tabular}{|c|c|c|c|}
\hline & $\begin{array}{l}\text { senses in the } \\
\text { forest }\end{array}$ & $\begin{array}{l}\text { meditation in feeling the five senses in } \\
\text { forest }\end{array}$ & $\begin{array}{l}\text { path } \\
\text { Mandara made from } \\
\text { natural things } \\
\text { Meditation with herbal } \\
\text { tea }\end{array}$ \\
\hline 4th & $\begin{array}{c}\text { Reducing } \\
\text { one's own stress }\end{array}$ & $\begin{array}{l}\text { Having the chance and tranquility of mind } \\
\text { to feel and introspect on the functional } \\
\text { physical fitness at the present time via } \\
\text { Qi-Gong }\end{array}$ & $\begin{array}{l}\text { Qi-Gong on the } \\
\text { functional physical } \\
\text { fitness }\end{array}$ \\
\hline 5 th & $\begin{array}{l}\text { Finding positive } \\
\text { self-image }\end{array}$ & $\begin{array}{l}\text { Reducing one's own stress } \\
\text { Giving one's confidence a boost } \\
\text { Sharing each other experiences }\end{array}$ & $\begin{array}{l}\text { Dancing therapy } \\
\text { Making color wheel } \\
\text { with nature things } \\
\text { Speaking with the } \\
\text { value card }\end{array}$ \\
\hline 6th & Final step & $\begin{array}{l}\text { Reducing one's own stress } \\
\text { Understanding the forest, oneself, and } \\
\text { others around through feelings and } \\
\text { experiences, and changes in oneself, and } \\
\text { sharing different thoughts. }\end{array}$ & $\begin{array}{l}\text { Forest bathing } \\
\text { Meditation with herbal } \\
\text { tea }\end{array}$ \\
\hline
\end{tabular}

\subsection{Research Tools}

\subsubsection{Job Search Stress}

Job search stress was modified and complemented by Kang[22]. A job search stress questionnaire was developed by Hwang[23] based on the Cornell University's Cornell Medical Index (CMI)[24]. This questionnaire consists of 22 questions grouped into four sub-factors: personality stress, family environment stress, academic stress, and school stress. All statements used a 5-point Likert scale ranging from 'strongly disagree' to 'strongly agree'. A higher score indicated higher job search stress. Cronbach's alpha in Kang's study[22] was .91, and in this study, it was 90 .

\subsubsection{Serum Cortisol}

Serum cortisol reflecting a reliable increase under stress, was measured as a physiological index. Clinical assistants and researchers collected blood samples of $5 \mathrm{~mL}$ each using a disposable syringe directly from the median cubital vein in front of the elbow. The procedures were performed in the morning before the forest healing program and after completing the program to adjust for the circadian rhythm. Blood samples collected at the field site were immediately placed in a freezer and sent to a laboratory. The collected samples were analyzed 
with a competitive immunoenzymatic assay using a BECKMAN COULTER Unicel DxI 800 ACCESS Immunoassay System.

\subsubsection{Career Decision-making Self-efficacy}

We used career decision-making self-efficacy index that was validated by Lee and Lee[25] by revising the career decision-making self-efficacy scale-short form (CDMSES-SF) developed by Betz and Voyten[26]. Twenty-five questions were divided into five sub-factors: self-assessment, job information, goal setting, planning, and problem-solving. Each question was scored on a 4-point Likert scale with higher scores indicating higher career decision-making self-efficacy. Cronbach's alpha was .91 in Lee and Lee[25], and .83 in this study.

\subsubsection{Career Resilience}

Career resilience is more than just an adaptation to careers, and a commitment to continuous learning and self-improvement for accomplishing future career goals with self-confidence under adverse circumstances caused by unexpected difficulties in achieving goals. It means the ability to continue and manage one's career actively[27]. Career resilience refers to the values measured using the tools developed by Kim[6]. It includes sub-factors of self-confidence, desire accomplishment, career self-reliance, cope with change, and utilizing one's relationship. Each sub-factor consisted of six questions and a total of 30 questions. A higher score on the 5-point Likert scale means higher career resilience. At the time of development, Cronbach's alpha was .93 and .96 in this study.

\section{Research Analysis Method}

The data collected in this study were analyzed using the SPSS 23.0 Windows statistical program as follows

First, the frequency and percentage of the general characteristics of the participants were calculated. Second, the reliability analysis was performed using the Cronbach's alpha coefficient to confirm the reliability of job search stress, career decision-making self-efficacy, and career resilience. Shapiro-Wilk test was performed to verify the normality of the result variables. Third, in order to compare before and after participation in forest healing program for each variable, the mean and standard deviations were checked and a paired t-test or Wilcoxon signed-rank test was conducted. The significance level was below $\mathrm{p}<0.05$. 
The Effect of Forest Healing Program on Job Search Stress, Career Decision-making Self-efficacy, and Career Resilience among Nursing College Students

\section{Results}

\subsection{General Characteristics of Participants}

The general characteristics of the participants are listed in Table 2. Of the 33 participants, 9.1\% were male and $90.9 \%$ were female. The age was below 30 years among $84.8 \%$ of the participants and above 30 years among $15.2 \%$ of them. The place of residence was metropolitan in $54.5 \%$ and in $45.5 \%$ it was Chuncheon-si. Employment was confirmed in $60.6 \%$ and $39.4 \%$ of the 13 participants were undecided.

[Table 2] General Characteristics of Participants $(\mathrm{N}=33)$

\begin{tabular}{|c|c|c|}
\hline Characteristic & Answer & $\mathrm{N}(\%)$ \\
\hline \multirow{2}{*}{ Gender } & male & $3(9.1)$ \\
\cline { 2 - 3 } & female & $30(90.9)$ \\
\hline \multirow{2}{*}{ Age } & $<30$ & $28(84.8)$ \\
\cline { 2 - 3 } & $>=30$ & $5(15.2)$ \\
\hline \multirow{2}{*}{ Residence } & Metropolitan area & $18(54.5)$ \\
\cline { 2 - 3 } & Chnucheon-si & $15(45.5)$ \\
\hline \multirow{2}{*}{ Career decision } & confirmed & $20(60.6)$ \\
\cline { 2 - 3 } & not yet & $13(39.4)$ \\
\hline
\end{tabular}

\subsection{The Effect of Forest Healing Program}

\subsubsection{Job Search Stress}

As shown in Table 3, there was no significant different in job search stress after the forest healing program $(\mathrm{P}=.105)$. In detail, regarding job search stress according to the general characteristics, the mean value after the program significantly decreased only in the group who did not find employment $(\mathrm{P}=.035)$.

\subsubsection{Serum Cortisol}

As shown in Table 4, there was no significant different in the serum cortisol level, although the mean value decreased from 7.71 to $7.06(\mathrm{P}=.217)$. Also, serum cortisol level according to the general characteristics did not significantly changed in all subgroups.

\subsubsection{Career Decision-making Self-efficacy}


As shown in Table 5, the career decision-making self-efficacy significantly increased from 3.31 to 3.49 ( $\mathrm{P}=.018)$. In detail, regarding career decision-making self-efficacy according to the general characteristics, the mean value after the program significantly increased in the female group $(\mathrm{P}=.030)$, aged below 30 year group $(\mathrm{P}=.046)$, metropolitan residents group $(\mathrm{P}=.006)$, and those with confirmed employment $(\mathrm{P}=.005)$.

\subsubsection{Career Resilience}

As shown in Table 6, the career resilience in this study did not change significantly, although the mean value increased from 3.56 to 3.65 ( $\mathrm{P}=.292)$. Specifically, about career resilience according to the general characteristics, the mean value after the program was significantly increased only in the group that confirmed employment $(\mathrm{P}=.009)$.

[Table 3] Changes in Job Search Stress Before and After the Forest Healing Program

\begin{tabular}{|c|c|c|c|c|c|c|c|}
\hline \multirow{2}{*}{ Job search stress } & \multicolumn{2}{c|}{ Pre-test } & \multicolumn{2}{c|}{ Post-test } & \multirow{2}{*}{ t or Z } & \multirow{2}{*}{$\mathrm{P}$} \\
\cline { 2 - 8 } Gender & Male & 1.70 & 0.78 & 1.53 & 0.51 & $-1.069^{\dagger}$ & .285 \\
\cline { 2 - 8 } & Female & 2.00 & 0.62 & 1.84 & 0.61 & 1.517 & .140 \\
\hline \multirow{2}{*}{ Age } & $<30$ & 1.94 & 0.66 & 1.78 & 0.61 & $-1.373^{\dagger}$ & .170 \\
\cline { 2 - 8 } & $>=30$ & 2.18 & 0.38 & 2.00 & 0.64 & $-1.095^{\dagger}$ & .273 \\
\hline \multirow{2}{*}{ Residence } & Metropolitan & 1.80 & 0.53 & 1.76 & 0.63 & $-0.545^{\dagger}$ & .586 \\
\cline { 2 - 8 } & Chunchen-si & 2.16 & 0.70 & 1.87 & 0.59 & 1.672 & .117 \\
\hline \multirow{2}{*}{$\begin{array}{c}\text { Career } \\
\text { decision }\end{array}$} & Confirmed & 1.73 & 0.48 & 1.73 & 0.70 & $-0.121^{\dagger}$ & .904 \\
\cline { 2 - 8 } & Not yet & 2.36 & 0.68 & 1.95 & 0.38 & 2.407 & .035 \\
\hline \multicolumn{2}{|c|}{ Total } & 1.97 & 0.63 & 1.81 & 0.61 & 1.672 & .105 \\
\hline
\end{tabular}

$+=\mathrm{Z}$ value, Wilcoxon sign rank test done

[Table 4] Changes in Serum Cortisol Level Before and After the Forest Healing Program

\begin{tabular}{|c|c|c|c|c|c|c|c|}
\hline \multirow{2}{*}{ Serum cortisol level } & \multicolumn{2}{|c|}{ Pre-test } & \multicolumn{2}{c|}{ Post-test } & \multirow{2}{*}{ t or Z } & \multirow{2}{*}{$\mathrm{P}$} \\
\cline { 3 - 8 } \multicolumn{2}{|c|}{} & $\mathrm{M}$ & $\mathrm{SD}$ & $\mathrm{M}$ & $\mathrm{SD}$ & & .109 \\
\hline \multirow{2}{*}{ Gender } & Male & 10.70 & 0.60 & 9.26 & 1.52 & $-1.604^{\dagger}$ & .313 \\
\cline { 2 - 8 } & Female & 7.35 & 2.31 & 6.79 & 2.63 & $-1.009^{\dagger}$ & .153 \\
\hline \multirow{2}{*}{ Age } & $<30$ & 8.06 & 2.42 & 7.28 & 2.68 & $-1.429^{\dagger}$ & .715 \\
\cline { 2 - 8 } & $>=30$ & 5.63 & 1.13 & 5.75 & 2.18 & $-0.365^{\dagger}$ & .427 \\
\hline \multirow{2}{*}{ Residence } & Metropolitan & 8.57 & 2.26 & 7.94 & 3.17 & $-0.795^{\dagger}$ & .270 \\
\cline { 2 - 8 } & Chunchen & 6.73 & 2.30 & 6.04 & 1.33 & 1.157 & .679 \\
\hline \multirow{2}{*}{$\begin{array}{c}\text { Career } \\
\text { decision }\end{array}$} & Confirmed & 7.26 & 2.46 & 7.03 & 2.77 & $-0.414^{\dagger}$ & .133 \\
\cline { 2 - 8 } & Not yet & 7.77 & 2.13 & 6.82 & 2.34 & 1.622 & .217 \\
\hline \multicolumn{2}{|c|}{} & 7.71 & 2.42 & 7.06 & 2.63 & 1.264 & \\
\hline
\end{tabular}

$\dagger=\mathrm{Z}$ value, Wilcoxon sign rank test done 
The Effect of Forest Healing Program on Job Search Stress, Career Decision-making Self-efficacy, and Career Resilience among Nursing College Students

[Table 5] Changes in Career Decision-making Self-efficacy Before and After the Forest Healing Program

\begin{tabular}{|c|c|c|c|c|c|c|c|}
\hline \multirow{2}{*}{\multicolumn{2}{|c|}{$\begin{array}{c}\text { Career decision-making } \\
\text { self-efficacy }\end{array}$}} & \multicolumn{2}{|c|}{ Pre-test } & \multicolumn{2}{|c|}{ Post-test } & \multirow{2}{*}{$\mathrm{t}$ or $\mathrm{Z}$} & \multirow{2}{*}{$\mathrm{P}$} \\
\hline & & M & $\mathrm{SD}$ & $\mathrm{M}$ & $\mathrm{SD}$ & & \\
\hline \multirow{2}{*}{ Gender } & Male & 3.75 & 0.12 & 3.96 & 0.30 & $-1.342^{\dagger}$ & .180 \\
\hline & Female & 3.27 & 0.39 & 3.44 & 0.46 & -2.276 & .030 \\
\hline \multirow{2}{*}{ Age } & $<30$ & 3.36 & 0.41 & 3.49 & 0.43 & -2.088 & .046 \\
\hline & $>=30$ & 3.03 & 0.13 & 3.48 & 0.72 & $-1.753^{\dagger}$ & .080 \\
\hline \multirow{2}{*}{ Residence } & Metropolitan & 3.33 & 0.37 & 3.56 & 0.41 & -3.144 & .006 \\
\hline & Chunchen & 3.29 & 0.44 & 3.41 & 0.53 & -0.908 & .379 \\
\hline \multirow{2}{*}{$\begin{array}{c}\text { Career } \\
\text { decision }\end{array}$} & Confirmed & 3.34 & 0.34 & 3.65 & 0.46 & -3.139 & .005 \\
\hline & Not yet & 3.26 & 0.48 & 3.25 & 0.38 & 0.150 & .884 \\
\hline \multicolumn{2}{|c|}{ Total } & 3.31 & 0.40 & 3.49 & 0.47 & -2.502 & .018 \\
\hline
\end{tabular}

$\dagger=\mathrm{Z}$ value, Wilcoxon sign rank test done

[Table 6] Changes in Career Resilience Before and After the Forest Healing Program

\begin{tabular}{|c|c|c|c|c|c|c|c|}
\hline \multirow{2}{*}{\multicolumn{2}{|c|}{ Career resilience }} & \multicolumn{2}{|c|}{ Pre-test } & \multicolumn{2}{|c|}{ Post-test } & \multirow{3}{*}{$\begin{array}{l}t \text { or } Z \\
-1.069^{\dagger}\end{array}$} & \multirow{3}{*}{$\begin{array}{c}\mathrm{P} \\
.285\end{array}$} \\
\hline & & \multirow{2}{*}{$\begin{array}{c}\mathrm{M} \\
4.09\end{array}$} & \multirow{2}{*}{$\begin{array}{c}\text { SD } \\
0.26\end{array}$} & \multirow{2}{*}{$\begin{array}{c}\mathrm{M} \\
3.96\end{array}$} & \multirow{2}{*}{$\begin{array}{c}\text { SD } \\
0.52\end{array}$} & & \\
\hline Condor & Male & & & & & & \\
\hline Gender & Female & 3.51 & 0.74 & 3.62 & 0.58 & -1.237 & .226 \\
\hline \multirow{2}{*}{ Age } & $<30$ & 3.56 & 0.65 & 3.64 & 0.57 & -0.869 & .392 \\
\hline & $>=30$ & 3.56 & 1.15 & 3.73 & 0.70 & $-0.405^{\dagger}$ & .686 \\
\hline \multirow{2}{*}{ Residence } & Metropolitan & 3.54 & 0.61 & 3.74 & 0.44 & -1.960 & .067 \\
\hline & Chunchen & 3.59 & 0.86 & 3.55 & 0.72 & 0.289 & .777 \\
\hline \multirow{2}{*}{$\begin{array}{c}\text { Career } \\
\text { decision }\end{array}$} & Confirmed & 3.66 & 0.61 & 3.79 & 0.58 & -2.920 & .009 \\
\hline & Not yet & 3.41 & 0.94 & 3.32 & 0.63 & 0.038 & .970 \\
\hline \multicolumn{2}{|c|}{ Total } & 3.56 & 0.72 & 3.65 & 0.58 & -1.072 & .292 \\
\hline
\end{tabular}

$\dagger=\mathrm{Z}$ value, Wilcoxon sign rank test done

\section{Discussion}

In our study, there was no significant difference in job search stress, although the mean value decreased from 1.97 to $1.81(\mathrm{P}=.105)$. These results differed from the other study results showing a significant decrease in employment stress among the subjects in the experimental group due to the effects of forest healing program on employment stress and anxiety among college students[28]. Many studies have reported that forest experiences significantly reduced the stress[28-30]. In this study, the degree of job search stress before test was 1.97, which was lower than that of general college students $(2.76 \sim 3.04)[28]$ and nursing college students (2.11)[31], and all-female students (2.21)[32]. The low level of job search stress during pretest may have made it difficult to induce significant changes. Currently, there are no difficulties in 
finding employment for nursing college students due to the lack of hospital nursing personnel, and many students who have confirmed their employment appear to have low stress levels. The group with higher levels of job search stress, such as students who did not confirm employment, were more sensitive to effect of the stress reduction following the healing program.

Cortisol is a stress hormone facilitating defensive response. In many scientific fields, serum cortisol levels has been used as a physiological indicator. In this study, there was no significant difference in serum cortisol level, although the mean value decreased from 7.71 to 7.06 $(\mathrm{P}=.217)$. In previous studies investing the effect of forest experience on male and female college students and adult female workers, the subjective stress index decreased significantly. In contrast, serum cortisol level was not significantly decreased[33] but rather increased after the experiment[14]. Another study of adult men and women reported a significant decrease in salivary cortisol in men after forest experience, but not in women[34]. Studies suggest that the effects of forest experience on blood cortisol levels are inconsistent and require further study.

Career decision-making self-efficacy indicates the self-confidence that you can successfully perform career-related tasks[5] and has the effect of mediating job stress[11]. In this study, the career decision-making self-efficacy increased significantly from 3.31 to 3.49 ( $\mathrm{P}=.018)$. This finding is consistent with that of previous studies demonstrating that forest activity had a positive effect on the mental health of elementary school students and the psychological well-being of adolescents[35][36]. Forests have the ability to promote physical and mental health by positively stimulating human physiology and senses[37]. A person who has high self-efficacy believes in his ability to complete the work and achieve better results. During the forest healing program, participants looked inside themselves, meditated on negative thoughts, and understood themselves and their peers to accurately assess theirs abilities, values and needs. It is believed that these activities have a positive effect on the belief that they will be able to navigate themselves when faced with career difficulties.

The other important element to overcome career stress and career barriers is career resilience[8]. The career resilience in this study did not change significantly, although the mean value increased from 3.56 to $3.65(\mathrm{P}=.292)$. Few previous studies have evaluated the effectiveness of forest healing on career recovery, making it difficult to compare directly with the results of this study. However a previous study showed their effectiveness in increasing the self-resilience of multi-cultural students[38]. Career elasticity is an individual's personality trait that can overcome stress in situations such as adversity or hardships related to careers. Career-resilient individuals pursue their goals, adapt and succeed, even in uncertain and 
The Effect of Forest Healing Program on Job Search Stress, Career Decision-making Self-efficacy, and Career Resilience among Nursing College Students

frustrating situations. Therefore career resilience is a necessary factor for not only successful employment but also job retention among students who undergo major changes before college graduation and employment. Although career resilience was increased by this forest healing program, it was not significant because of the characteristics of variables.

\section{Conclusion}

The purpose of this study was to investigate the effect of forest healing program on job search stress, career decision-making self-efficacy, career resilience and serum cortisol levels of 33 th grade nursing college students. The study was a single group pre-test post-test design. The forest healing program was composed of climate, diet, exercise, and plant elements available in school forests based on the advice of five forest healing experts. The program involved six sessions of one hour each held on a weekly basis, from October 17th to November 19th, of 2019.

As a result, the career decision-making self-efficacy increased significantly from 3.31 to 3.49 after the forest healing program. There was no significant difference in job search stress, serum cortisol, career resilience. However, dividing into the general characteristics, job search stress decreased significantly in the group of students who did not find employment $(\mathrm{P}=.035)$ and career resilience increased significantly in the group that confirmed employment $(\mathrm{P}=.009)$.

Therefore, this study was meaningful in that the forest healing program had a positive effect on reducing negative emotions such as employment stress of the research participants. It increased positive emotions such as career decision-making self-efficacy and career elasticity. In addition, the availability of school forests with easy access to target areas for forest healing programs was confirmed. The results reflect a single-group pre- and post-experimental design for fourth grade nursing students of $S$ university. The findings cannot be generalized to all the nursing college students.

Based on the study findings, we suggest that the forest healing program should be applied to various targets according to the preferences and research goals of the participating students.

\section{Acknowledgement}

This study was supported by the academic research fund of Songgok University. 


\section{References}

[1] http://news.wowtv.co.kr/NewsCenter/News/Read?articleId=A201912090259\&t=KO, Dec 9 (2019)

[2] H. K. Shin, J. Y. Chang, The relationship among personality characteristics, gender, job-seeking stress and mental health in college seniors, Korean Journal of Clinical Psychology, (2003), Vol.22, No.4, pp.815-827.

[3] B. J. Kim, A Study of Life Events Influenced on Happiness of College Students, Korean Journal of Social and Personality Psychology, (2011), Vol.25, No.1, pp.115-135. DOI: 10.21193/kjspp.2011.25.1.007

[4] C. E. Park, D. J. Kim, C. S. Shin, Y. H. Kim, Effects of Forest Healing Programs on Resilience and Happiness of Employees - For University Employees -, Korean Journal of Environment and Ecology, (2018), Vol.32, No.6, pp.667-675. DOI: 10.13047/KJEE.2018.32.6.667

[5] Hackett, G., Betz, N. E., The relationship of career-related self-efficacy expectations to perceived career options in college women and men, Journal of Counseling Psychology, (1981), Vol.28, No.5, pp.399-410. DOI: $10.1037 / 0022-0167.28 .5 .399$

[6] M. K. Kim, The Development of the Career Resilience Scale for College Students, Kyung pook National university, Unpublished Master's Dissertation, (2013)

[7] London, M., Toward a theory of career motivation, Academy of Management Review, (1983), Vol.8, No.4, pp.620-630. DOI: $10.2307 / 258263$

[8] London, M., Mone, E. M., CCareer management and survival in the workplace: Helping employees make tough career decisions, stay motivated, and reduce career stress., San Francisco : Jossey-Bass, (1987)

[9] Shin, H. K and J. Y. Jang, The relationship among persongality characteristics, gender, job-seeking stress and mental health in college seniors, Korean Journal of Clinical Psychology, (2003), Vol.22, No.4, pp.815-827. UCI : G704-000007.2003.22.4.009

[10] T. S. Kim, K. H. Lee, The Mediating Effect of Career Decision Making Self-Efficacy in the Relation between Narcissism and Career Decision Level in College Students, Asian Journal of Education, (2012), Vol.13, No.4, pp.123-141. DOI: 10.15753/aje.2012.13.4.006

[11] M. O. Kim, Y. S. Park, The Relationship between Career Preparing Behavior and Jobs Seeking Stress in University students: Morderation Effect of Career Decision-Making Self-Efficacy, Korean Journal of Youth Studies, (2012), Vol.19, No.11, pp.69-90. UCI : G704-000387.2012.19.11.011

[12] Duffy, Ryan. D., Allan, Blake. A., Dik, Bryan. J., The Presence of a Calling and Academic Satisfaction: Examining Potential Mediators, Journal of Vocational Behavior, (2011), Vol.79, No.1, pp.74-80. DOI: 10.1016/j.jvb.2010.11.001

[13] P. D. Eom, M. C. Whang, Effects of Viewing Environments of Valley, Forest Road, and City on Emotional State based on Autonomic Nervous System, The Journal of Korean Institute of Forest Recreation, (2015), Vol.19, No.4, pp.1-12. DOI : 10.34272/forest.2015.19.4.001

[14] W. H. Jung, J. M. Woo, J. S. Ryu, Effect of a forest therapy program and the forest environment on female workers' stress, Urban Forestry and Urban Greening, (2015), Vol.14, No.2, pp.274-281. DOI: 10.1016/j.ufug.2015.02.004 
[15] W. S. Shin, P. S. Yeoun, R. W. Yoo, C. S. Shin, Forest experience and psychological health benefits: The state of the art and future prospect in korea, Environmental Health and Preventive Medicine, (2010), Vol.15, No.1, pp.38-47. DOI: 10.1007/s12199-009-0114-9

[16] J. H. Song, W. S. Shin, P. S. Yeoun, M. D. Choi, The Influence of Forest Therapeutic Program on Unmarried Mothers' Depression and Self-Esteem, Journal of Korean Society of Forest Science, (2009), Vol.98, No.1, pp.82-87. UCI : G704-000375.2009.98.1.010

[17] S. H. Park, B. J. Park, Effects of Weekend Forest Healing Program Utilizing Urban Forest on Improvement of Family Cohesion and Family Relationship and Parental Satisfaction, The Journal of Korean Institute of Forest Recreation, (2018), Vol.22, No.4, pp.49-58. DOI: 10.34272/forest.2018.22.4.005

[18] H. S. Cho, S. J. Kim J. G. Cha, S. M. Cho, Development of a scale for measuring effectiveness of forest experience, stress (KSSM), (2009), Vol.17, No.2, pp.143-153. UCI: G704-002182.2009.17.2.005

[19] Y. M. Cho, The influence of forest experience program on sociality and depression, anxiety of children from low income families, Chungbuk National University, Unpublished Master's Thesis, (2011)

[20] S. Kim, H. Seo, Basic Study for the Development of Forest Education Teacher Training Program for Early Childhood Teachers, International Journal of Child Warfare Promotion and Management. (2017), Vol.1, No.1, pp.45-52. DOI: $10.21742 /$ ijcwpm.2017.1.1.08

[21] S. Y. Lee, M. J. Chung, Forest School Character Education Program for Elementary School Children: Development and Efficacy, International Journal of Child Warfare Promotion and Management, (2017), Vol.1, No.1, pp.71-76. DOI: 10.21742/ijcwpm.2017.1.1.12

[22] Y. R. Kang, The influence of job seeking stress on their career maturity dance majoring students, Dan kook University, Unpublished Master's Thesis, (2006)

[23] S. W. Hwang, A study on employment stress of university students, Dong-a University, Unpublished Master's Thesis, (1998)

[24] Shepherd, M., Cooper, B., Brown, A. C., Kalton, G. W., Psychiatric illness in general practice, London: Oxford University Press, (1966)

[25] K. H. Lee, H. J. Lee, Effects of Career Self - Efficacy in Predicting the Level of Career Attitude Maturity of College Students, Korean Psychological Association, (2000), Vol.12, No.1, pp.127-136.

[26] N. E. Betz, K. K. Voyten, Efficacy and Outcome Expectations Influence Career Exploration and Decidedness, The Career Development Quarterly, (1997), Vol.46, No.2, pp.179-189. DOI: 10.1002/J.2161-0045.1997.TB01004.X

[27] R. W. Lent, S. D. Brown, G. Hackett, Contextual supports and barriers to career choice: A social cognitive analysis, Journal of Counseling Psychology, (2002), Vol.47, No.1, pp.36-49. DOI: 10.1037/0022-0167.47.1.36

[28] D. J. Kim, S. S. Lee, Effects of forest therapy program in school forest on employment stress and anxiety of university students, Journal of People, Plants, and Environment, (2014), Vol.17, No.2, pp.107-115. DOI: 10.11628/ksppe.2014.17.2.107

[29] J. H. Song, J. G. Cha, C. Y. Lee, Y. S. Choi, P. S. Yeon, Effects of forest healing program on stress response and spirituality in female nursing college students and there experience, The Journal of Korean 
[30] J. W. Lee, P. S. Yeon, S. H. Park, J. W. Kang, Effects of Forest Therapy Programs on the Stress and Emotional Change of Emotional Labor Workers, The Journal of Korean institute of Forest Recreation, (2018), Vol.22, No.3, pp.15-22. DOI : 10.34272/forest.2018.22.3.002

[31] S. A. Yang, Convergence Analysis of the Factors Influencing Job-Seeking Stress in Nursing Students, Journal of Convergence for Information Technology, (2017), Vol.7, No.4, pp.171-183. DOI : 10.22156/CS4SMB.2017.7.4.171

[32] E. Y. Cho, J. A. Kim, J. Y. Kim, H. J. Kim, E. S. Ra, H. Y. Lee, The Factors Influencing Employment Stress of Nursing Students, The journal of Convergence on Culture Technology, (2016), Vol.2, No.1, pp.35-43. DOI : 10.7236/JCCT.2016.2.1.35

[33] H. K. Kim, S. J. Son, Y. Hur, H. Choi, Effects of Stress Hormone (Cortisol) from the Healthy Forest Experience Program in Deogyusan National Park, Journal of Environment Health Science, (2018), Vol.44, No.5, pp.502-513.

[34] B. G. Lee, H. H. Lee, A Study on the Effects of Human Physiology after Forest Phytoncide Therapy, Journal of Naturopathy, (2012), Vol.1, No.1, pp.14-20.

[35] S. A. Kim, D. W. Joung, G. W. Kim and B. J. Park, The effects of forest activities on attitudes toward forest and mental health of Elementary school Students, The Journal of the Korean Institute of Forest Recreation, (2015), Vol.19, No.4, pp.35-43. DOI: 10.34272/forest.2015.19.4.004

[36] Y. M. Cho, D. J. Kim, P. S. Yeoun, H. K. Kwon, H. S. Cho and J. M. Lee, The influence of a seasonal forest education program on psychological well-being and stress of adolescents, Journal of the Korean Institute of Forest Recreation, (2014), Vol.18, No.2, pp.59-69. DOI: 10.34272/forest.2014.18.2.006

[37] K. W. Kim, Theoretical study of characteristics of therapeutic elementsand application to forest therapy, Journal of People, Plants, and Environment, (2006), Vol.9, No.4, pp.111-123. UCI : G704-001350.2006.9.4.013

[38] C. S. Jang, C. S. Shin, B. S. Jang, Md. Omar Sharif, Effects of Forest Healing Programs Using School Forests on Language Acquisition and Ego-resilience of Multicultural Background Students, Korean Journal of Environment and Ecology, (2019), Vol.33, No.3, pp.333-340. DOI: 10.13047/KJEE.2019.33.3.333 